\title{
PERUBAHAN PENGGUNAAN LAHAN DAN KEBUTUHAN LAHAN PERMUKIMAN DI KOTA BONTANG, KALIMANTAN TIMUR
}

\author{
Land Use Change and Land Requirement for Settlement in Bontang, \\ East Borneo
}

Muji Esti Wahyudi' ${ }^{1}$, Khursatul Munibah² and Widiatmaka²

Diterima: 12 Februari 2018

Disetujui: 17 Agustus 2018

\begin{abstract}
Abstrak: Kota Bontang merupakan kota termuda di Provinsi Kalimantan Timur yang berbasis pada sektor industri dengan pertumbuhan penduduk dan ekonomi wilayah yang relatif tinggi. Tujuan penelitian ini adalah (a) mengidentifikasi penggunaan lahan di Kota Bontang tahun 2002, 2009 dan 2016 (b) menganalisis perubahan dan memprediksi penggunaan lahan tahun 2023 (c) menganalisis kesesuaian dan ketersediaan lahan permukiman dan (d) menganalisis kebutuhan lahan permukiman. Metode analisis yang digunakan diantaranya analisis tumpang susun, kesesuaian lahan dan kebutuhan lahan permukiman. Hasil analisis menunjukkan terdapat sekitar enam penggunaan lahan yang dominan, yaitu hutan, semak, mangrove, permukiman, industri, dan ladang. Perubahan penggunaan lahan terbesar adalah dari hutan menjadi semak. Luas lahan permukiman pada tahun 2016 sekitar 1.770 ha dan diprediksi mengalami peningkatan yang paling tinggi dibanding penggunaan lahan lainnya pada tahun 2023. Hasil evaluasi kesesuaian lahan menunjukkan terdapat sekitar 4.864 ha atau $30,71 \%$ lahan yang berada pada kelas sesuai untuk permukiman. Ketersediaan lahan diluar kawasan permukiman eksisting sekitar 941,5 ha yang mampu mencukupi kebutuhan lahan permukiman bahkan hingga tahun 2050.
\end{abstract}

\section{Kata kunci: perubahan penggunaan lahan, kesesuaian lahan, permukiman}

\begin{abstract}
Bontang is the youngest city in East Kalimantan which focused to industrial sector. As the industry city, Bontang has been growing rapidly especially for population and regional development. This study was aimed to (a) identified land use in Bontang at 2002, 2009 and 2016 (b) analyze land use change and land use prediction in 2023 (c) evaluate land suitability and availability for settlement and (d) to estimate the land required for settlement in Bontang. The research was conducted by overlay method, matching system based on minimum limiting factor and descriptive analysis. Results analysis showed that actual land use in Bontang (2016) was dominated by bush, forest, mangrove, settlement, industry and plantation area. Dominant land use change (2002-2016) in Bontang was forest to bush. The area of settlement in 2016 was about 1.770 ha and predicted to be the highest increased compared to other land use in 2023. Land suitability analysis showed that 4.864 ha or $30,71 \%$ of this region was in suitable class fo settlement. The availability of suitable land settlement exclude the existing was about 941,5 ha, which could meet the needs of settlement up to 2050.
\end{abstract}

Keywords: land use change, land suitability, settlement

\footnotetext{
${ }^{1}$ Program Studi Ilmu Perencanaan Wilayah, Sekolah Pascasarjana IPB

${ }^{2}$ Departemen Ilmu Tanah dan Sumberdaya Lahan, Fakultas Pertanian IPB
} 


\section{PENDAHULUAN}

Undang-Undang Nomor 26 Tahun 2007 tentang Penataan Ruang menyatakan kawasan perkotaan adalah wilayah yang mempunyai kegiatan utama bukan pertanian dengan susunan fungsi kawasan sebagai tempat permukiman perkotaan, pemusatan dan distribusi pelayanan jasa pemerintahan, pelayanan sosial dan kegiatan ekonomi. Umumnya wilayah perkotaan memiliki ciri dominasi lahan terbangun dan jumlah penduduk yang relatif tinggi. Luo et al. (2011) menyatakan lebih dari 50\% jumlah penduduk di seluruh dunia berada di wilayah perkotaan. Indonesia sebagai salah satu negara yang paling terurbanisasi di asia, sejak tahun 2013 populasi perkotaannya telah melampaui populasi pedesaan. Data BPS menunjukkan pada tahun 2015 populasi perkotaan di Indonesia telah mencapai 135 juta jiwa atau sekitar 53\% dari jumlah total populasi (BPS 2015). Bank Dunia bahkan memperkirakan pada tahun 2025 jumlah populasi urban di Indonesia akan mencapai 68\% (Samad et al. 2016). Secara umum laju pertumbuhan penduduk perkotaan di kota-kota kecil lebih tinggi dari pada di kota-kota besar (Fahmi et al. 2014).

Tingginya jumlah penduduk perkotaan baik yang diakibatkan pertumbuhan alami maupun migrasi berimplikasi pada makin besarnya tekanan penduduk terhadap lahan kota, khususnya untuk tempat tinggal dan lahan untuk fasilitas-fasilitas pendukung lainnya (Ruslisan et al. 2015; Sadyohutomo, 2016). Batudoka (2005) menyatakan dua pertiga bagian kota adalah perumahan dan permukiman, karenanya arah perkembangan permukiman kota perlu dicermati (Nurhidayati et al. 2016).

Faktor pendorong utama perubahan penggunaan lahan perkotaan adalah pembangunan wilayah (Pribadi et al. 2006) dan tingkat pertumbuhan penduduk (Sitorus et al. 2012; Jat et al. 2017). Perubahan penggunaan lahan tidak dapat dipungkiri merupakan salah satu bentuk konsekuensi dari adanya pertumbuhan dan perkembangan di suatu wilayah (Rustiadi et al. 2011; Harahap 2013). Perubahan penggunaan lahan cenderung mengarah pada alih fungsi lahan pertanian menjadi lahan non-pertanian atau dari lahan non terbangun menjadi lahan terbangun.

Kota Bontang merupakan kota termuda di Provinsi Kalimantan Timur, awalnya hanya sebuah kecamatan di Kabupaten Kutai yang mengalami perkembangan pesat salah satunya karena keberadaan industri PT. Badak NGL yang mengelola industri gas alam dan PT. Pupuk Kaltim yang mengelola industri pupuk dan amoniak, dan akhirnya menjadi kota otonom pada tahun 1999. Memiliki laju pertumbuhan penduduk hingga 4,4\%, tertinggi di Kalimantan Timur bahkan dibandingkan dengan kota utama seperti Balikpapan dan Samarinda yang masing-masing sekitar 3,8\% dan 3,9\%.

Luasan wilayah daratan Kota Bontang sekitar 15.837,5 ha, dimana di dalamnya terdapat kawasan kehutanan sekitar 5.294 ha dan lahan penguasaan skala besar untuk industri sekitar 3.588 ha, menunjukkan lahan efektif untuk pembangunan dan pengembangan kota cukup terbatas. Berdasarkan RPJMN dan Perpres Nomor 146 Tahun 2015 tentang Pelaksanaan Pembangunan dan Pengembangan Kilang Minyak di Dalam Negeri, di Kota Bontang akan dibangun Kilang Minyak baru yang diyakini akan berdampak besar bagi perkembangan Kota Bontang baik secara fisik maupun sosial ekonomi.

Penggunaan dan pemanfaatan ruang di suatu daerah sebenarnya diatur dalam Rencana Tata Ruang, namun sering terjadi kondisi aktual implementasinya mengalami penyimpangan atau bahkan perencanaannya yang masih kurang tepat. Perencanaan penggunaan lahan bertujuan untuk mendapatkan manfaat yang optimal dengan memilih penggunaan berdasarkan daya dukung atau kemampuan dan kesesuaian lahannya untuk mencegah terjadinya degradasi lahan (Susetyo et al. 2014; Widiatmaka et al. 2015; Sadesmesli et al. 2017). Permasalahan perkotaan dan permukiman yang sering terjadi adalah banjir dan munculnya kawasan kumuh (Harahap 2013; Malau 2013), yang salah satu penyebabnya adalah kurangnya perhatian terhadap daya dukung dan daya tampung 
wilayah. Untuk itu diperlukan perencanaan penggunaan lahan yang berkelanjutan dan mempertimbangkan daya dukung lingkungan.

Penginderaan Jauh dan Sistem Informasi Geografis dapat digunakan untuk memetakan dan menganalisis perkembangan kota serta menganalisis perubahan penutupan lahan (Pigawati et al. 2017). Kajian perubahan penggunaan lahan telah banyak dilakukan dan umumnya menggunakan citra resolusi rendah (Hidayat et al. 2015; Yudarwati et al. 2016; Septiono dan Mussadun 2016; Prabowo et al. 2017). Penelitian ini mencoba mengkaji dengan menggunakan citra resolusi tinggi berupa yang dapat menghasilkan kelas penggunaan/penutupan lahan yang lebih detail seperti dilakukan oleh Malarvizhi et al. (2015). Adapun tujuan dari penelitian ini adalah:

1. Mengidentifikasi penggunaan lahan tahun 2002, 2009 dan tahun 2016;

2. Menganalisis perubahan dan prediksi penggunaan lahan tahun 2023;

3. Menganalisis kesesuaian dan ketersediaan lahan permukiman; dan

4. Menganalisis kebutuhan lahan permukiman di Kota Bontang

\section{METODE}

\section{Lokasi Penelitian}

Penelitian ini dilaksanakan di Kota Bontang yang secara geografis terletak pada $0^{\circ} 1^{\prime}$ Lintang Utara - $0^{\circ} 12$ Lintang Utara dan $117^{\circ} 23^{\prime}$ Bujur Timur - $1^{\circ} 7^{\circ} 38^{\prime}$ Bujur Timur. Penelitian dilakukan di wilayah daratan Kota Bontang, lokasi wilayah penelitian disajikan pada Gambar 1.

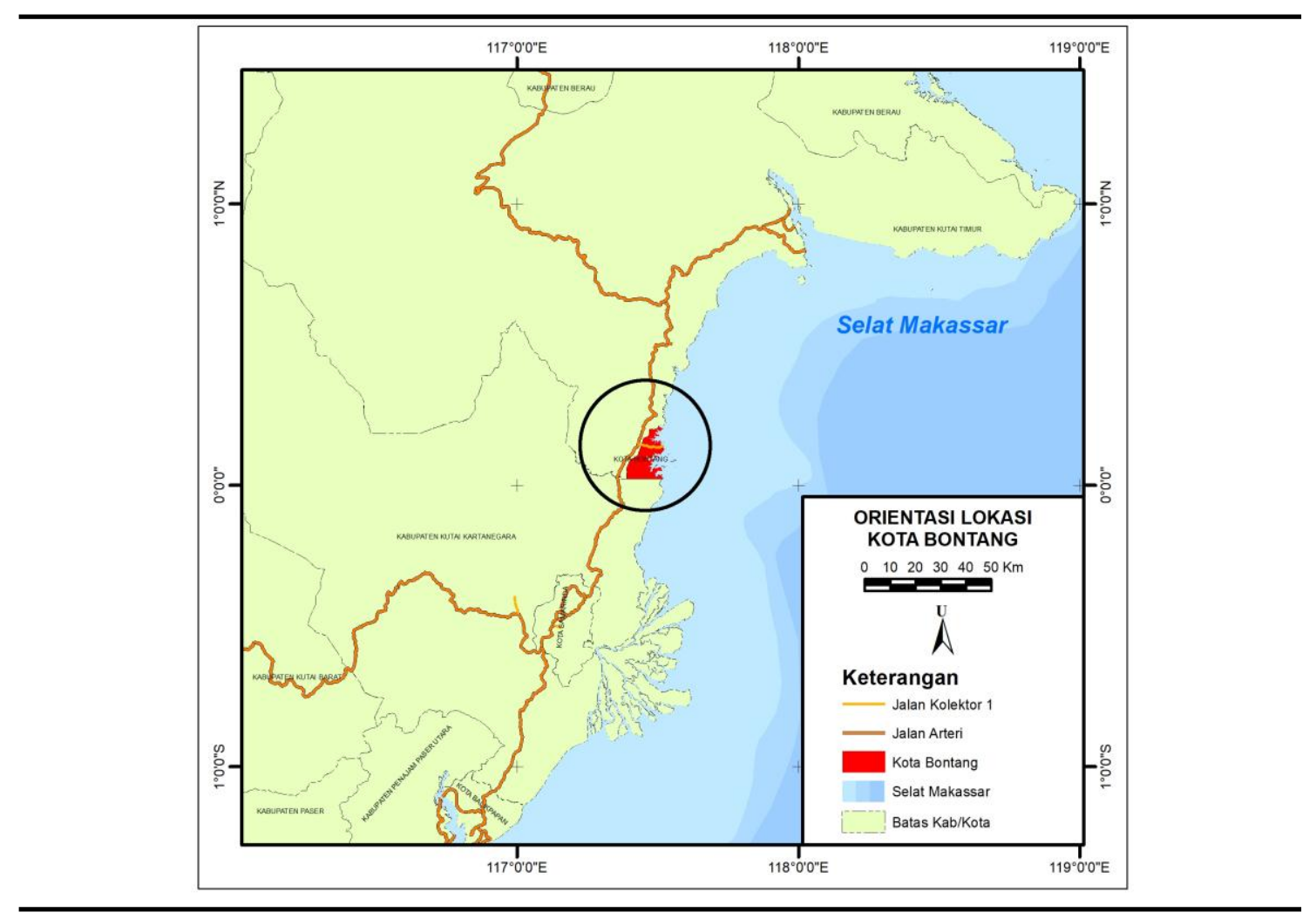

Gambar 1 Orientasi Lokasi Kota Bontang

\section{Identifikasi Penggunaan Lahan}

Identifikasi penggunaan/penutupan lahan diawali dengan proses interpretasi citra resolusi tinggi (Quickbird dan Google Earth) tahun 2002, 2009 dan 2016. Citra Quickbird 
didapat dari Bapelitbang Kota Bontang, sedangkan Citra Google Earth didapatkan dari aplikasi Google Earth yang diunduh dan dikonversi ke format gambar dengan bantuan software CacheStasher dan ChacheMaster untuk mendapatkan file jpg beserta file bergeoreferensi untuk setiap gambarnya. Agar didapatkan hasil citra yang memiliki resolusi tinggi, proses streaming harus sudah mencapai $100 \%$ dan pada ketinggian $<1 \mathrm{~km}$. Terakhir dilakukan proses mozaik dan konversi ke format GeoTIFF. Klasifikasi penggunaan lahan disusun berdasarkan SNI 7645-1:2014 tentang Klasifikasi Penutup Lahan dan Tata Cara Kerja Neraca Penatagunaan Tanah ATR/ BPN 2016 dengan beberapa penyesuaian berdasarkan kebutuhan penelitian. Selanjutnya dilakukan verifikasi hasil interpretasi dengan pengecekan lapangan yang diambil secara purposive sampling dengan mempertimbangkan aksesibilitas untuk mencapai lokasi. Deliniasi lebih rinci dilakukan pada kawasan permukiman dilakukan dengan mengidentifikasi berdasarkan fungsi dan lokasinya.

\section{Perubahan dan Prediksi Penggunaan Lahan}

Analisis perubahan penggunaan lahan dilakukan dengan metode overlay antara peta penggunaan lahan tahun 2002, 2009 dan 2016. Keluaran dari tahapan ini adalah matriks perubahan penggunaan lahan. Tahap selanjutnya adalah membuat prediksi penggunaan lahan tahun 2023 dengan pertimbangan pada tahun tersebut merupakan periode 5 tahunan revisi Rencana Tata Ruang Wilayah Kota Bontang. Pemodelan dilakukan dengan menggunakan metode markov chain dan cellular automata. Tujuan utama prediksi adalah untuk melihat perkembangan kawasan permukiman secara spasial, karena itu skenario yang dilakukan adalah business as usual. Pada tahap ini dilakukan reklasifikasi kelas penggunaan lahan untuk penyederhanaan dalam proses prediksi.

\section{Kesesuaian dan Ketersediaan Lahan Permukiman}

Evaluasi kesesuaian lahan untuk permukiman dilakukan dengan menggunakan kriteria kawasan peruntukan permukiman berdasarkan Peraturan Menteri Pekerjaan Umum No 41/PRT/M/2007 tentang Pedoman Kriteria Teknis Kawasan Budidaya dengan pendekatan kerangka FAO (2007) menggunakan metode matching (Nowar et al. 2015 dan Widiatmaka et al. 2016) yaitu mencocokkan antara karakteristik dan kondisi lahan dengan kriteria kesesuaian lahan.

Tabel 1 Kriteria kesesuaian untuk permukiman

\begin{tabular}{|c|c|c|c|c|c|}
\hline Faktor & S1 & $\mathrm{S} 2$ & S3 & N1 & N2 \\
\hline Lereng (l) 1) & $0-8 \%$ & $8-15 \%$ & $15-25 \%$ & $25-45 \%$ & $>45 \%$ \\
\hline Jarak dari sungai $\left.(r)^{2}\right)$ & $>10 \mathrm{~m}$ & - & - & $3-10 \mathrm{~m}$ & $\leq 3 \mathrm{~m}$ \\
\hline Jarak dari laut $(\mathrm{s})^{3)}$ & $>100 \mathrm{~m}$ & - & - & $\leq 100 \mathrm{~m}$ & - \\
\hline Jarak dari pipa gas $\left.(g)^{4}\right)$ & $>50 \mathrm{~m}$ & - & - & $10-50 \mathrm{~m}$ & $<10 \mathrm{~m}$ \\
\hline Jarak dari industri (i) ${ }^{5}$ & - & - & $<2000 \mathrm{~m}$ & - & - \\
\hline Penggunaan lahan (m) & - & - & - & Tubuh air, Sawah, mangrove & - \\
\hline Drainase $(d)$ & baik & - & - & terhambat & - \\
\hline
\end{tabular}

Keterangan:

1) Kepmentan No. 837 Tahun 1980

2) Permen PUPR Nomor 28/PRT/M/2015

3) Perpres Nomor 51 tahun 2016

4) Kepmentamben Nomor 300.K/38/M.PE/1997 dan PTK BP Migas Nomor 012/PTK/II/2007

5) Permenperin No 40/M-IND/PER/6/2016

Kelas kesesuaian lahan untuk permukiman yang dihasilkan dari analisis ini adalah kelas S1 (sangat sesuai), S2 (cukup sesuai), S3 (sesuai marginal) dan N1 (tidak sesuai saat ini) dan N2 (tidak sesuai permanen). Pengelompokan didasarkan pada faktor penghambat 
terberat (minimum limiting factor). Sedangkan ketersediaan lahan permukiman disusun dengan mempertimbangkan kriteria seperti yang disajikan pada Tabel 2.

Tabel 2 Kriteria ketersediaan lahan permukiman

\begin{tabular}{cll}
\hline No & \multicolumn{1}{c}{ Faktor } & \multicolumn{1}{c}{ Keterangan } \\
\hline 1 & Kesesuaian lahan & Berada pada lahan sesuai (S1,S2,S3) \\
2 & Kawasan kehutanan & Di luar kawasan kehutanan \\
3 & Pola Ruang RTRW & Berada pada alokasi lahan permukiman \\
4 & Penggunaan lahan tahun 2016 & Kawasan non terbangun (semak, kebun, ladang, lahan terbuka, \\
& & penggalian sirtu) \\
5 & Penguasaan tanah & Di luar HGB dan HP perusahaan \\
\hline
\end{tabular}

\section{Kebutuhan Lahan Permukiman}

Jumlah dan proyeksi penduduk menjadi dasar dalam memprediksi kebutuhan lahan perumahan dan permukiman. Salah satu model proyeksi yang umum digunakan adalah saturasi (Munibah et al. 2009) termasuk dalam penelitian ini karena memiliki nilai $\mathrm{R}^{2}$ yang paling tinggi dibanding dengan model lainnya.

Keterangan:

$$
Y=\frac{w * \exp (b * X)}{(1+\exp (b * X)}
$$

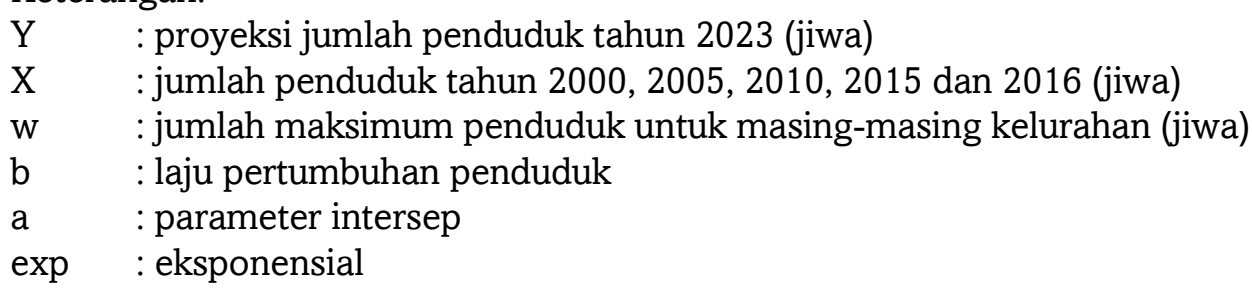

Kebutuhan lahan untuk permukiman meliputi lahan untuk kavling rumah dan lahan untuk sarana prasarana pendukungnya. Perhitungan jumlah rumah/kavling menggunakan asumsi 4 jiwa untuk $1 \mathrm{KK} /$ rumah. Luas kavling menggunakan luas minimal berdasarkan SNI dan luas rata-rata kavling di Kota Bontang yaitu $100 \mathrm{~m}^{2}$ dan $200 \mathrm{~m}^{2}$. Sedangkan lahan untuk sarana prasarana pendukung terdiri dari lahan sarana pendukung, lahan prasarana jalan dan lahan Ruang Terbuka Hijau (RTH).

Keterangan:

$$
\begin{gathered}
\mathrm{K}_{\mathrm{LP}}=\mathrm{L}_{\mathrm{k}}+\mathrm{L}_{\mathrm{ps}} \\
\mathrm{L}_{\mathrm{k}}=\mathrm{JP} / 4{ }^{*} \mathrm{a} \\
\mathrm{L}_{\mathrm{ps}}=(100 / 140){ }^{*} \mathrm{~L}_{\mathrm{k}}
\end{gathered}
$$

$\mathrm{K}_{\mathrm{LP}} \quad$ : Kebutuhan lahan permukiman

JP : Jumlah penduduk

$\mathrm{L}_{\mathrm{k}} \quad$ : Lahan kavling rumah

a : $\quad 100 \mathrm{~m}^{2}$ (minimal SNI-3-1733-2004)

- $200 \mathrm{~m}^{2}$ (Rata-rata luas kavling)

Lps : Lahan sarana prasarana

- $\quad$ Lahan RTH 20\% (UU 26 Tahun 2007)

- Lahan prasarana jalan 5\% (SPM PU 534 Tahun 2001)

- Lahan sarana 15\% (SNI-3-1733-2004)

\section{HASIL DAN PEMBAHASAN}

\section{Identifikasi penggunaan lahan}

Penggunaan lahan di Kota Bontang berdasarkan hasil interpretasi citra menghasilkan 26 jenis penggunaan. Namun secara umum terdapat enam jenis penggunaan yang 
mendominasi yaitu hutan, semak, mangrove, permukiman, industri dan ladang yang mencapai $92 \%$. Sedangkan sisa penggunaan lainnya masing-masing $<1 \%$. Rincian luasan penggunaan lahan masing-masing tahun disajikan pada Tabel 3 dan Gambar 2.

Tabel 3 Luasan penggunaan lahan di Kota Bontang tahun 2002, 2009 dan 2016

\begin{tabular}{|c|c|c|c|c|c|c|c|}
\hline \multirow[t]{2}{*}{ No } & \multirow[t]{2}{*}{ Penggunaan Lahan } & \multicolumn{2}{|c|}{$\begin{array}{l}\text { Luas Lahan } \\
\text { Tahun } 2002\end{array}$} & \multicolumn{2}{|c|}{$\begin{array}{l}\text { Luas Lahan } \\
\text { Tahun } 2009\end{array}$} & \multicolumn{2}{|c|}{$\begin{array}{l}\text { Luas Lahan } \\
\text { Tahun } 2016\end{array}$} \\
\hline & & $\mathrm{Ha}$ & $\%$ & $\mathrm{Ha}$ & $\%$ & $\mathrm{Ha}$ & $\%$ \\
\hline 1 & Bandara & 21.5 & 0.14 & 21.5 & 0.14 & 21.5 & 0.14 \\
\hline 2 & Danau & 9.4 & 0.06 & 9.4 & 0.06 & 9.4 & 0.06 \\
\hline 3 & Hutan & $5,498.1$ & 34.72 & $5,025.9$ & 31.73 & $2,032.7$ & 12.83 \\
\hline 4 & Industri & 573.6 & 3.62 & 582.2 & 3.68 & 639.6 & 4.04 \\
\hline 5 & Kolam & 6.6 & 0.04 & 8.6 & 0.05 & 9.1 & 0.06 \\
\hline 6 & Ladang & 191.3 & 1.21 & 574.1 & 3.63 & 969.5 & 6.12 \\
\hline 7 & Lahan terbuka & 55.9 & 0.35 & 150.7 & 0.95 & 93.1 & 0.59 \\
\hline 8 & Lapangan terbang Layang & - & - & 22.7 & 0.14 & 22.7 & 0.14 \\
\hline 9 & Laut & 43.5 & 0.27 & 20.4 & 0.13 & 15.1 & 0.10 \\
\hline 10 & Makam & 3.4 & 0.02 & 4.2 & 0.03 & 4.8 & 0.03 \\
\hline 11 & Mangrove & $2,861.3$ & 18.07 & $2,883.3$ & 18.21 & $2,872.5$ & 18.14 \\
\hline 12 & Padang Golf & 111.6 & 0.70 & 111.6 & 0.70 & 111.6 & 0.70 \\
\hline 13 & Pelabuhan & - & - & 3.8 & 0.02 & 3.8 & 0.02 \\
\hline 14 & Penggalian Sirtu & 16.5 & 0.10 & 28.8 & 0.18 & 49.2 & 0.31 \\
\hline 15 & Perkantoran & 120.8 & 0.76 & 124.6 & 0.79 & 151.8 & 0.96 \\
\hline 16 & Perkebunan & - & - & 26.5 & 0.17 & 48.2 & 0.30 \\
\hline 17 & Pipeline & 167.7 & 1.06 & 167.7 & 1.06 & 167.7 & 1.06 \\
\hline 18 & Rawa & 55.8 & 0.35 & 55.3 & 0.35 & 54.9 & 0.35 \\
\hline 19 & Permukiman & $1,207.2$ & 7.62 & $1,558.7$ & 9.84 & $1,770.6$ & 11.18 \\
\hline 20 & Sawah & 24.0 & 0.15 & 16.8 & 0.11 & 40.4 & 0.26 \\
\hline 21 & Semak & $4,588.1$ & 28.97 & $4,204.8$ & 26.55 & $6,534.1$ & 41.26 \\
\hline 22 & Stadion/GOR & 15.9 & 0.10 & 27.3 & 0.17 & 27.3 & 0.17 \\
\hline 23 & Sungai & 47.6 & 0.30 & 47.6 & 0.30 & 47.6 & 0.30 \\
\hline 24 & Tambak & 217.1 & 1.37 & 147.1 & 0.93 & 126.4 & 0.80 \\
\hline 25 & Terminal & 0.8 & 0.01 & 0.8 & 0.01 & 0.8 & 0.01 \\
\hline \multirow[t]{2}{*}{26} & TPA & - & - & 13.0 & 0.08 & 13.0 & 0.08 \\
\hline & TOTAL & $15,837.5$ & 100.00 & $15,837.5$ & 100.00 & $15,837.5$ & 100.00 \\
\hline
\end{tabular}

Pada tahun 2002 hanya didapatkan 22 jenis penggunaan lahan yang kemudian pada tahun 2009 dan 2016 bertambah menjadi 26 jenis. Penggunaan lahan hutan selama tiga titik tahun mengalami penurunan yang sangat signifikan, dari 5.498 ha menjadi 2.032 ha. Penurunan terbesar terjadi pada periode 2009-2016 yang disebabkan terutama oleh kebakaran hutan yang melanda Kalimantan Timur termasuk Kota Bontang pada tahun 2015. Penggunaan lahan semak sempat mengalami penurunan pada periode 2002-2009, namun meningkat drastis pada periode 2009-2016. Meningkatnya penggunaan lahan semak yang merupakan penggunaan lahan transisi menunjukkan bahwa perkembangan Kota Bontang sedang dan masih akan berlanjut. Mangrove masuk dalam tiga penggunaan lahan terbesar karena posisi Kota Bontang yang berada di pesisir, menunjukkan luas yang relatif tidak berubah, menunjukkan bahwa kawasan pesisir relatif terjaga dengan baik. 


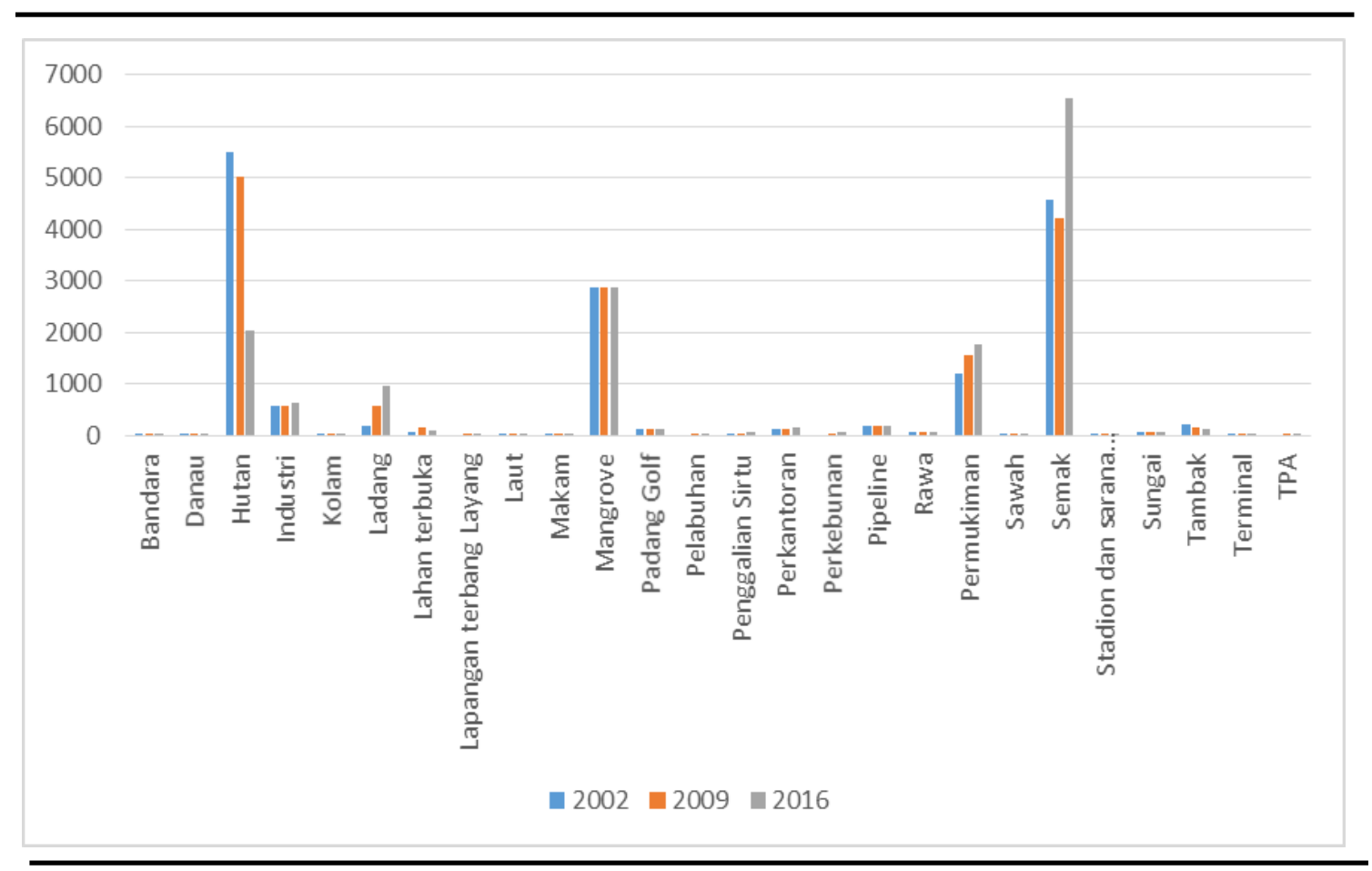

Gambar 2 Grafik Luasan Penggunaan Lahan Kota Bontang Tahun 2002, 2009 dan 2016

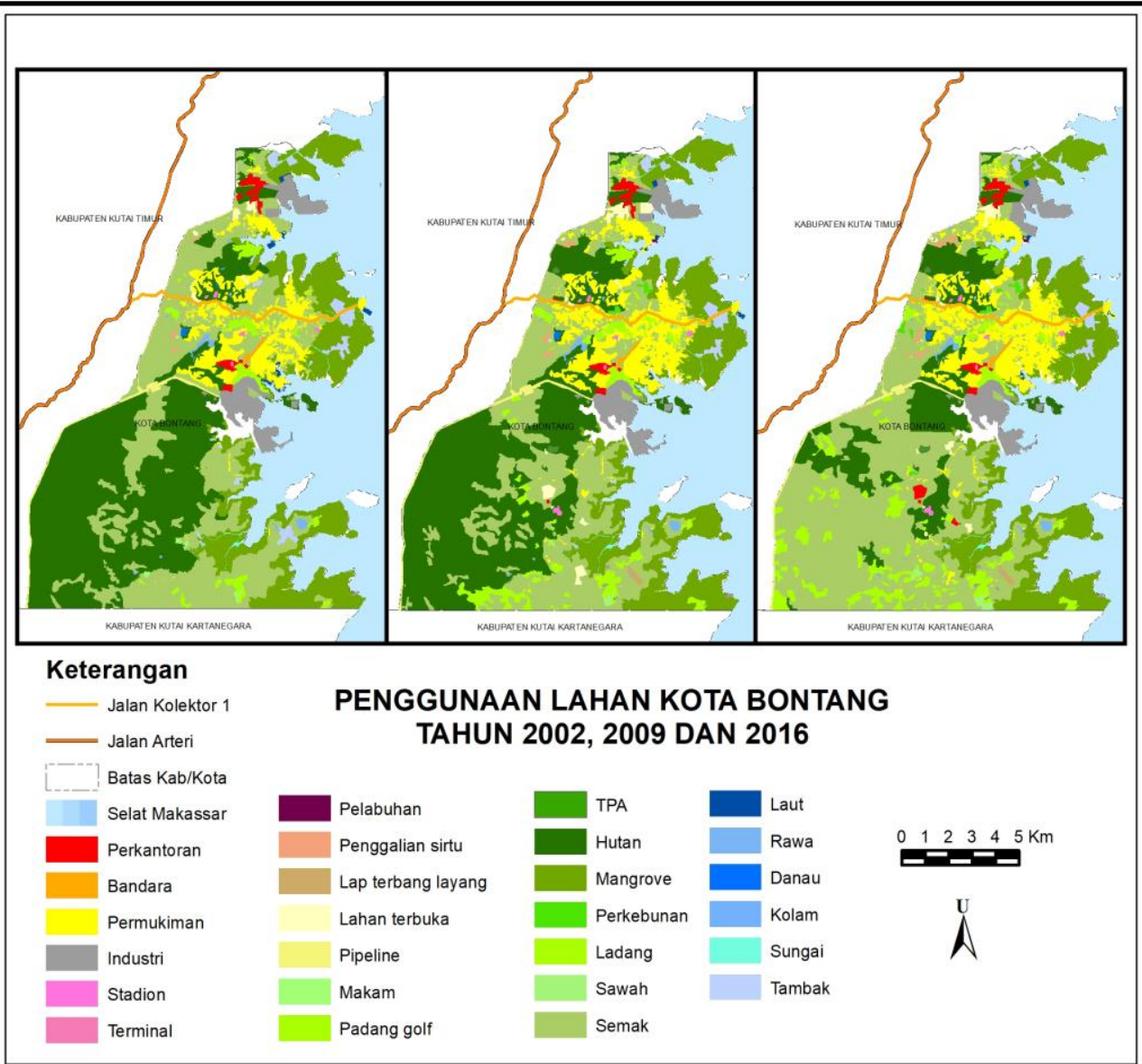


Gambar 3 Peta Penggunaan Lahan Kota Bontang Tahun 2002, 2009 dan 2016

Penggunaan lahan industri, ladang, dan permukiman secara konsisten selalu bertambah. Ladang bertambah hingga 778 ha, yang tertinggi setelah penggunaan semak, menunjukkan meningkatnya produktifitas lahan. Permukiman mengalami peningkatan hingga 563 ha, masih berpusat di wilayah bagian utara namun sudah mulai terlihat menyebar ke bagian selatan. Pemerintah Kota Bontang memang mulai mengembangkan wilayah selatan yang relatif masih belum berkembang dengan membuka akses jalan menuju ke selatan dan memindahkan pusat pemerintahan ke Kelurahan Bontang Lestari di bagian selatan.

\section{Identifikasi permukiman}

Permukiman merupakan salah satu penggunaan terbesar di Kota Bontang, berdasarkan karakteristik huniannya perumahan dan permukiman dapat menjadi perumahan umum dan perumahan khusus (Undang-Undang Nomor 1 Tahun 2011). Adapun perumahan khusus di Kota Bontang dapat digolongkan kedalam tiga jenis yaitu perumahan pesisir, industri umum dan industri khusus sebagai berikut:

1. Perumahan pesisir/di atas laut (R. Pesisir), permukiman yang terdiri atas perumahan dengan model rumah panggung dan terletak di pesisir/atas laut (Gambar 4). Permukiman tipe ini berada pada dua kelurahan yaitu Kelurahan Bontang Kuala dan Kelurahan Loktuan. Permukiman Bontang Kuala merupakan permukiman awal yang menjadi cikal bakal tumbuhnya Kota Bontang (Budiman et al. 2010).

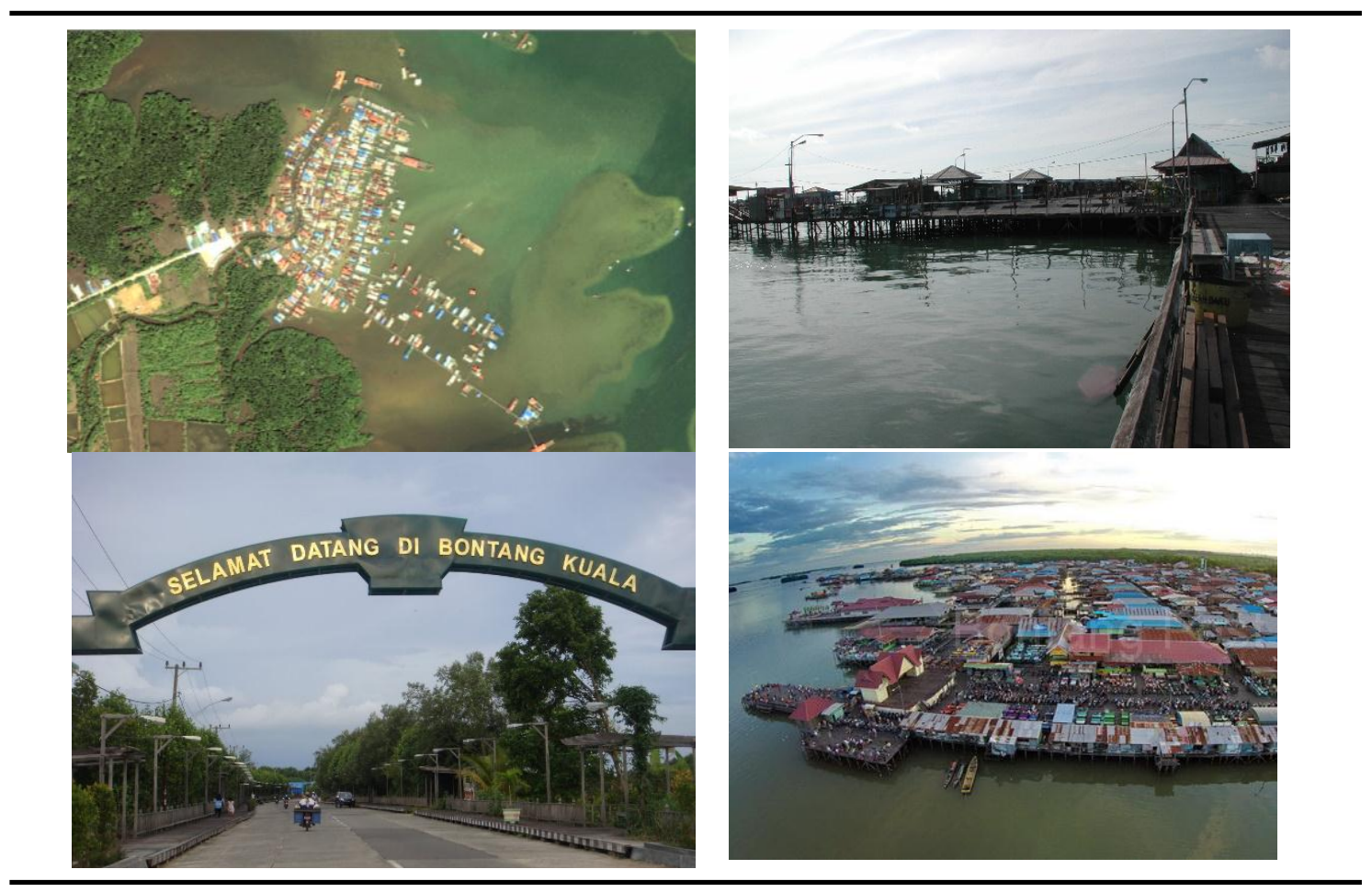

Gambar 4 Kondisi perumahan pesisir

2. Perumahan industri umum (R. Industri umum), disediakan oleh perusahaan untuk karyawannya dan dapat diberikan hak kepemilikan, disebut juga perumahan BTN atau HOP (house ownership program). Karakteristik perumahannya adalah 
tersusun secara teratur serta mendapat suplay listrik dan air bersih dari perusahaan. Lahan kavling di lingkungan ini cukup luas, rata-rata sekitar $300 \mathrm{~m}^{2}$ (Gambar 5);

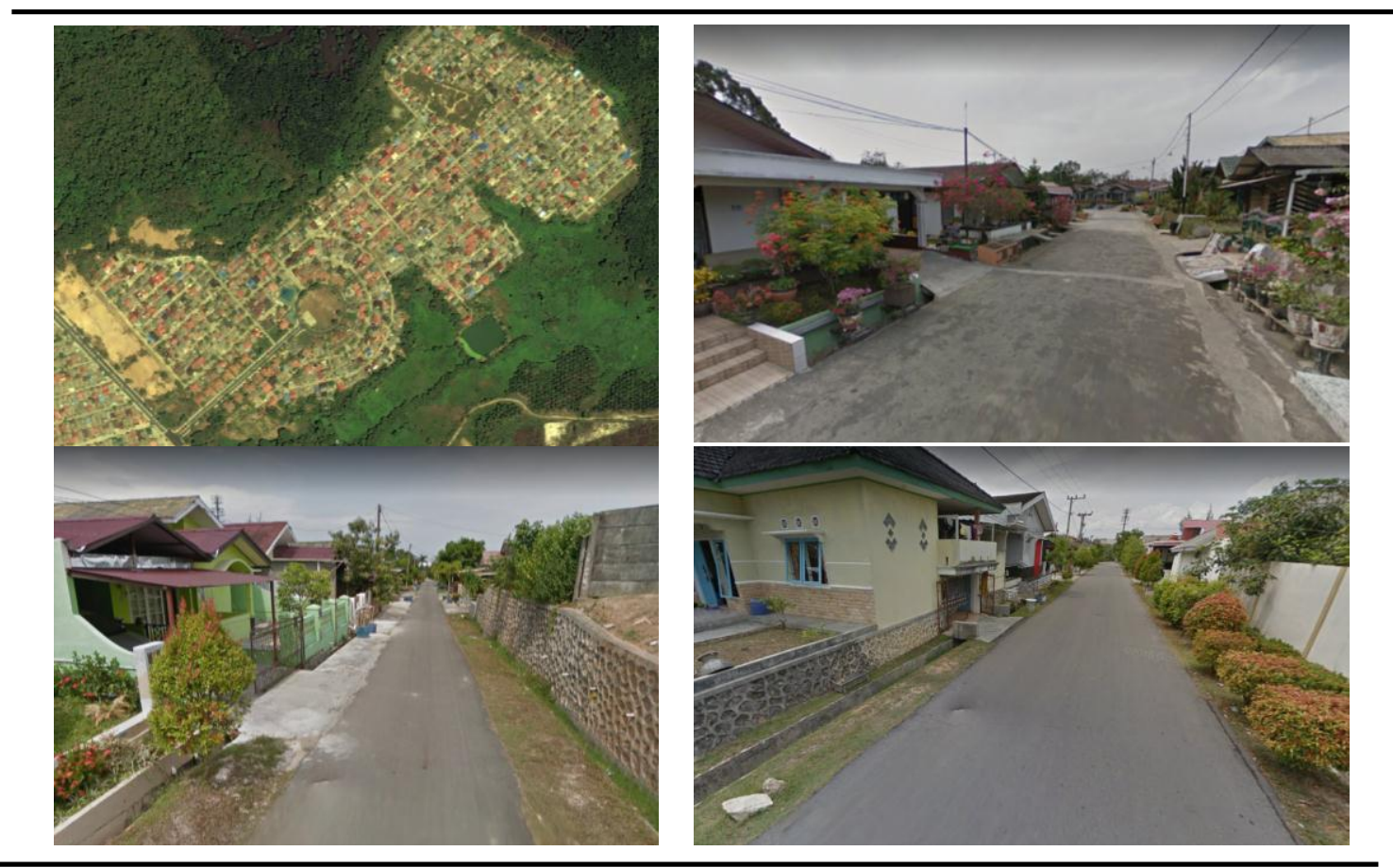

\section{Gambar 5 Perumahan industri umum}

3. Perumahan industri khusus (R. Industri khusus), merupakan perumahan dinas yang disediakan oleh perusahaan untuk karyawannya. Perumahan ini disebut juga Perumahan PC (personal community). Berdasarkan hasil perhitungan terdapat sekitar 997 unit rumah PC di PT.Badak LNG dan 552 unit di PT.Pupuk Kaltim dengan luas lahan rata-rata $800 \mathrm{~m}^{2}$ (Gambar 6).
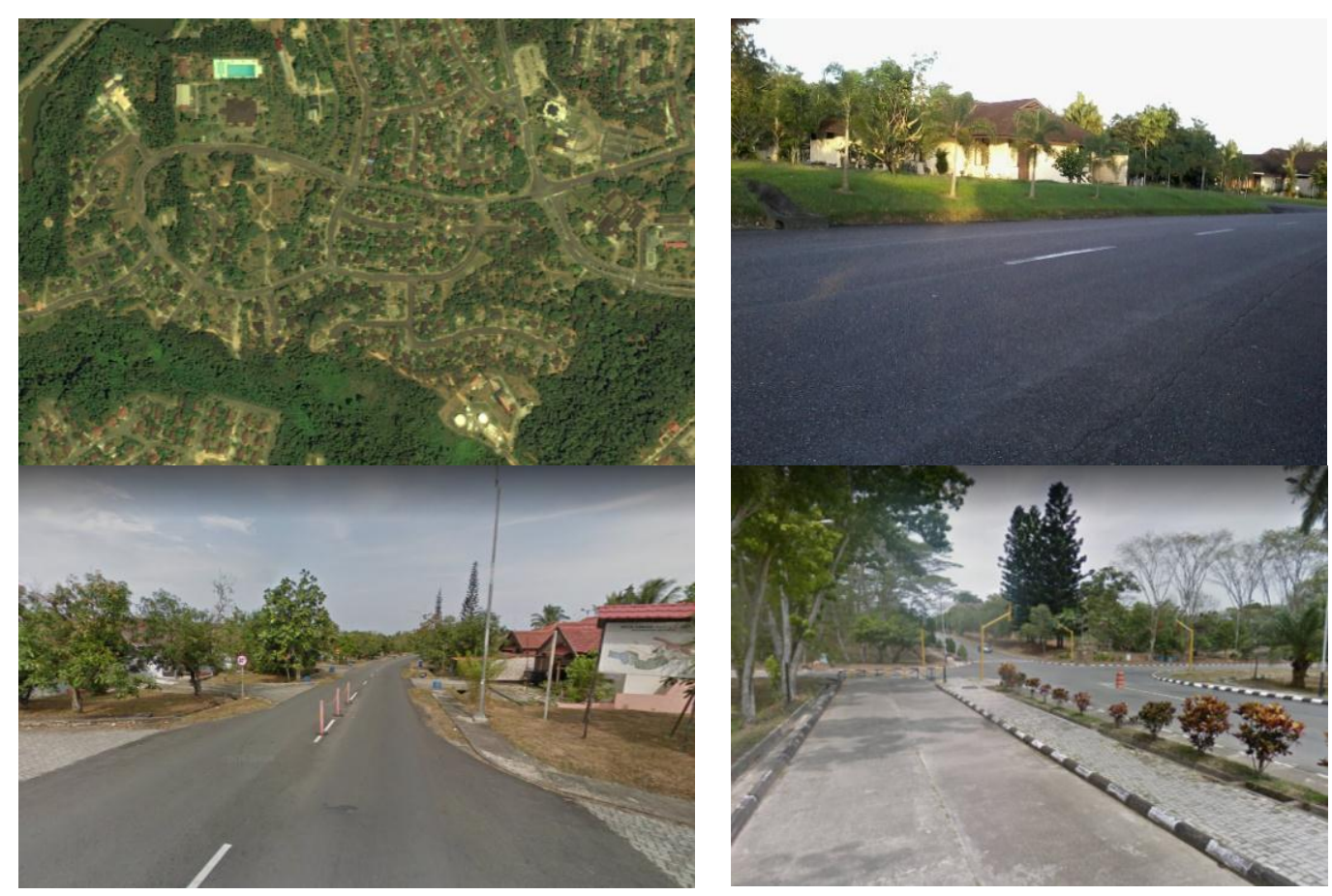

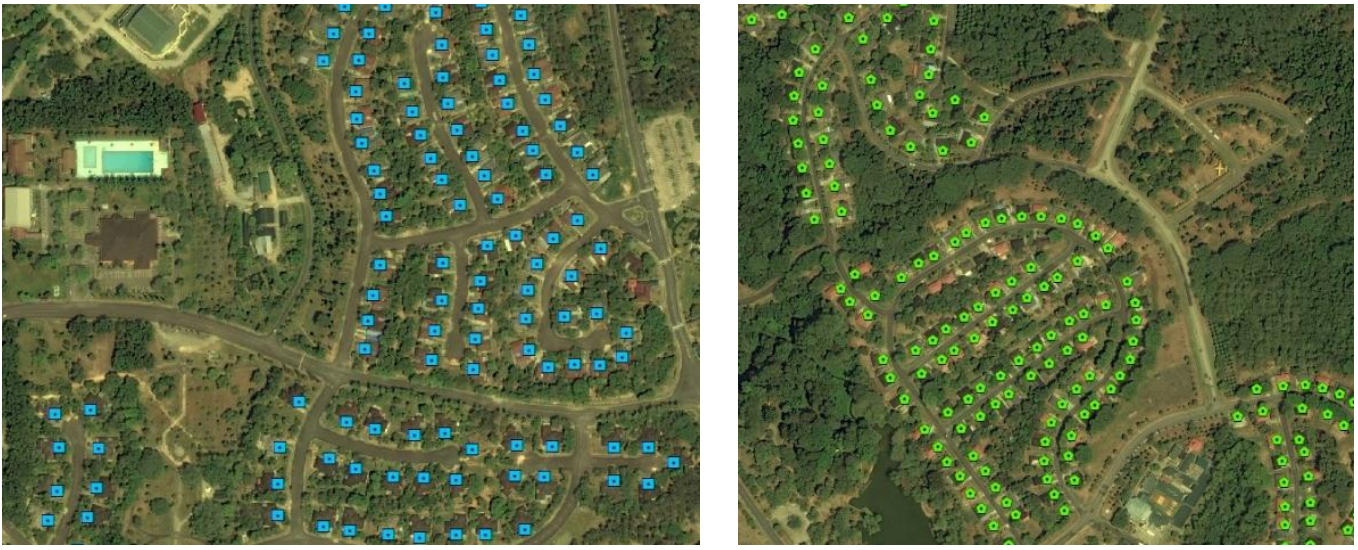

Gambar 6 Perumahan industri khusus

Perumahan umum memiliki sebaran dan luas paling besar, serta mengalami pertumbuhan tertinggi mencapai $71 \%$ pada periode tahun 2002-2016. Perumahan pesisir dan perumahan industri umum mengalami perkembangan walaupun tidak sebesar perumahan umum, masing-masing 56\% dan 13\%. Sedangkan perumahan industri khusus yang merupakan perumahan dinas yang disediakan oleh perusahaan tidak mengalami perubahan.

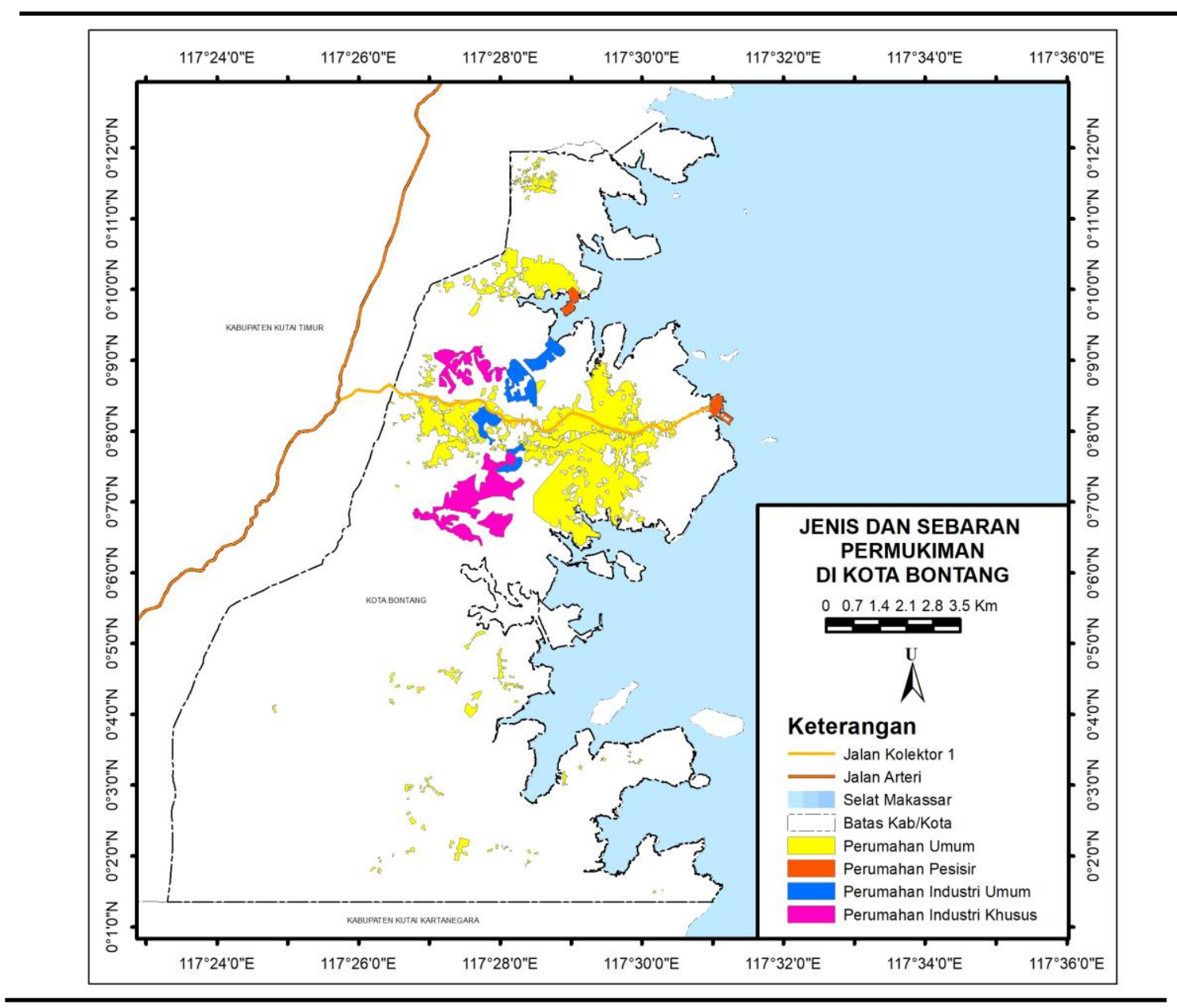

Gambar 7 Jenis dan Sebaran Permukiman di Kota Bontang Tahun 2016 
Tabel 4 Luasan masing-masing perumahan tahun 2002-2016

\begin{tabular}{|c|c|c|c|c|c|c|c|c|}
\hline \multirow{2}{*}{ Jenis } & \multicolumn{2}{|c|}{ Luas tahun 2002} & \multicolumn{2}{|c|}{ Luas tahun 2009} & \multicolumn{2}{|c|}{ Luas tahun 2016} & \multicolumn{2}{|c|}{$\begin{array}{c}\text { Penambahan } \\
\text { luas }\end{array}$} \\
\hline & $\mathrm{Ha}$ & $\%$ & $\mathrm{Ha}$ & $\%$ & $\mathrm{Ha}$ & $\%$ & $\mathrm{Ha}$ & $\%$ \\
\hline R. Umum & 741,1 & 61,39 & $1.068,5$ & 68,55 & $1.273,2$ & 71,91 & 532,1 & 71,81 \\
\hline R. Pesisir & 23,8 & 1,97 & 31,0 & 1,99 & 37,2 & 2,10 & 13,4 & 56,22 \\
\hline R. Industri umum & 127,9 & 10,59 & 144,7 & 9,29 & 145,7 & 8,23 & 17,9 & 13,96 \\
\hline R. Industri khusus & 314,5 & 26,05 & 314,5 & 20,17 & 314,5 & 17,76 & 0,0 & 0,00 \\
\hline TOTAL & $1.207,2$ & 100,00 & $1.558,7$ & 100,00 & $1.770,6$ & 100,00 & 563,4 & 46,67 \\
\hline
\end{tabular}

Perumahan umum tersebar dan dominan berada pada wilayah utara, sedangkan di wilayah selatan relatif lebih sedikit. Perumahan pesisir secara luasan relatif kecil, walaupun mengalami peningkatan diperkirakan kedepan akan relatif tetap mengingat adanya kebijakan Pemerintah Kota untuk membatasi sisi terluar wilayah tersebut. Perumahan industri umum dan khusus cenderung tidak bertambah karena kawasan tersebut sudah memiliki masterplan, terlebih pada perumahan industri khusus yang lahannya dimiliki oleh perusahaan.

\section{Perubahan dan Prediksi Penggunaan Lahan}

Penggunaan lahan yang paling banyak menjadi permukiman pada periode tahun 2002-2009 secara berturut-turut adalah semak, mangrove, hutan, ladang, laut, dan lahan terbuka. Sedangkan pada periode tahun 2009-2016 penggunaan lahan yang paling banyak menjadi permukiman adalah semak, ladang, mangrove, lahan terbuka, laut, dan hutan.

Pola perubahan penggunaan lahan tahun 2002-2009 dan tahun 2009-2016 memiliki kemiripan. Penggunaan lahan yang paling banyak mengalami perubahan adalah hutan dan semak, sedangkan penggunaan lahan yang paling banyak menjadi tujuan dari perubahan adalah semak dan permukiman.

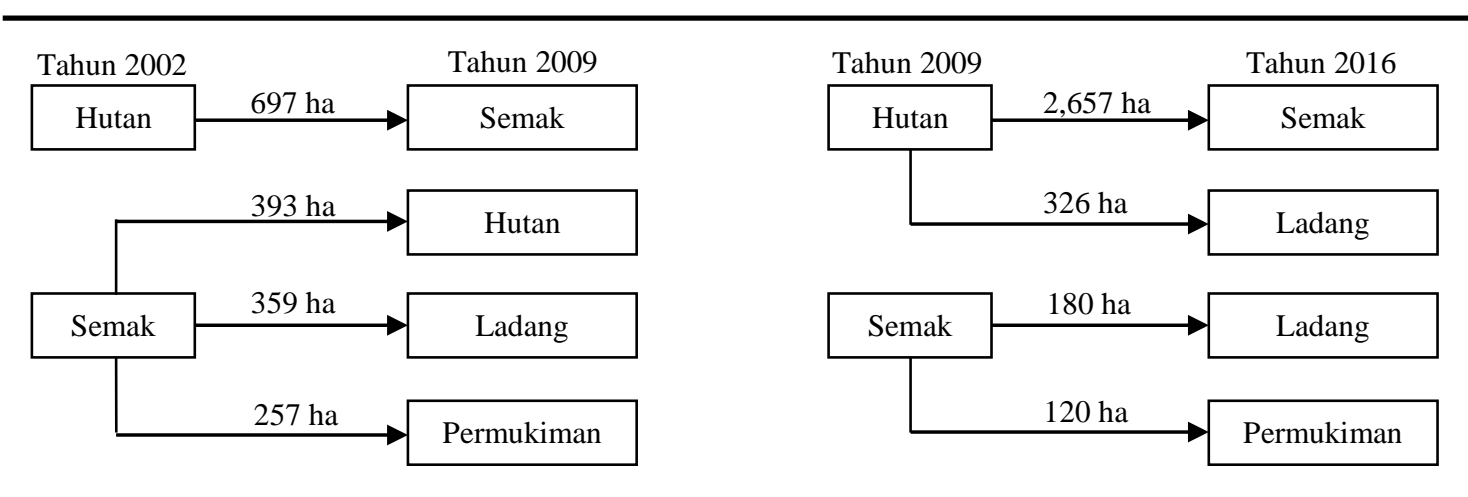

Gambar 8 Pola Perubahan Penggunaan Lahan di Kota Bontang

Prediksi penggunaan lahan tahun 2023 dilakukan dengan menjadikan peta penggunaan lahan tahun 2002 sebagai tahun dasar dalam analisis markov chain, kemudian tahun 2016 sebagai tahun dasar pada analisis cellular automata dengan jumlah iterasi sebanyak 7 kali. Sebelumnya dilakukan prediksi penggunaan lahan tahun 2016 untuk melihat nilai akurasi modelnya. Model dibangun dengan transition probabillity matrix (TPM) Tahun 2002-2009, tahun awal prediksi (T0) 2009. Hasil prediksi dengan menghasilkan nilai kappa 0,8574 atau 85\% yang menunjukkan model tersebut baik untuk digunakan dalam memprediksi penggunaan lahan tahun 2023 (Dwinanto et al. 2016). Kelas penggunaan lahan disederhanakan menjadi 14 kelas dalam melakukan prediksi. 
Tabel 5 Prediksi luas dan perubahan penggunaan lahan tahun 2023

\begin{tabular}{lrrrr}
\hline \multirow{2}{*}{ Penggunaan lahan } & Luas tahun & Luas tahun (prediksi) & \multicolumn{2}{c}{ Perubahan } \\
\cline { 3 - 5 } & 2016 (ha) & 2023 (ha) & ha & \% \\
\hline Fasum & 53,3 & 54,0 & 0,8 & 1,44 \\
Industri & 639,6 & 648,9 & 9,3 & 1,45 \\
Mangrove & $2.998,9$ & $2.950,2$ & $-48,7$ & $-1,63$ \\
Penggalian sirtu & 49,2 & 49,2 & $-0,1$ & $-0,11$ \\
Perkantoran & 151,7 & 155,3 & 3,6 & 2,37 \\
Pertanian & $1.058,2$ & $1.308,4$ & 250,2 & 23,65 \\
Pipeline & 167,7 & 167,8 & 0,1 & 0,03 \\
R. Umum & $1.273,2$ & $1.609,1$ & 335,9 & 26,38 \\
R. Pesisir & 37,2 & 43,1 & 5,9 & 15,78 \\
R. Industri umum & 145,7 & 145,8 & 0,1 & 0,06 \\
R. Industri khusus & 314,5 & 314,5 & 0,0 & 0,01 \\
Sungai & 47,6 & 46,3 & $-1,3$ & $-2,70$ \\
Tubuh air & 88,5 & 70,7 & $-17,8$ & $-20,12$ \\
Vegetasi lainnya & $8.812,1$ & $8.274,1$ & $-538,0$ & $-6,10$ \\
\multicolumn{1}{c}{ TOTAL } & $15.837,5$ & $15.837,5$ & & \\
\hline
\end{tabular}

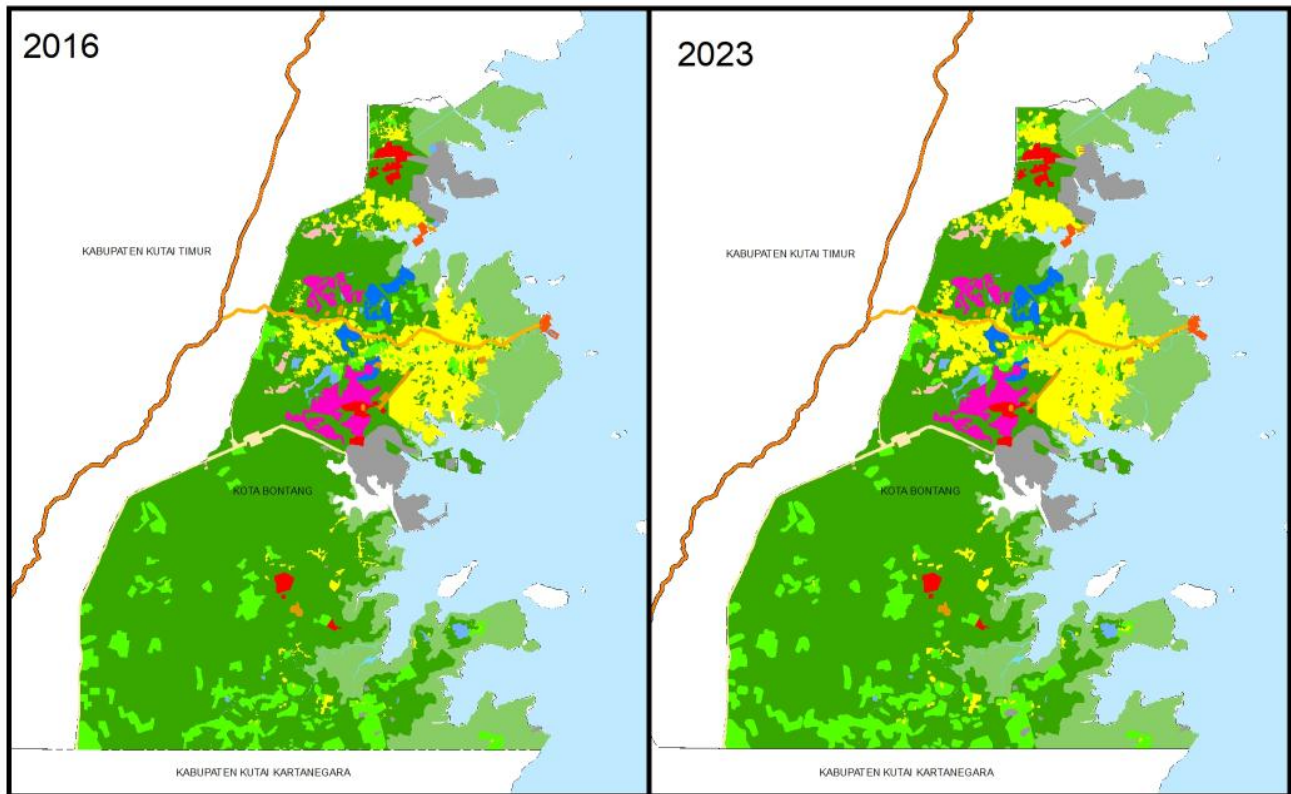

\section{Keterangan}

- Jalan Kolektor 1

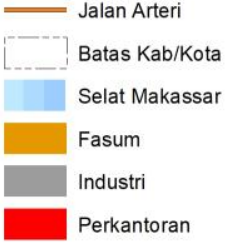

PENGGUNAAN LAHAN KOTA BONTANG TAHUN 2016 DAN PREDIKSI TAHUN 2023

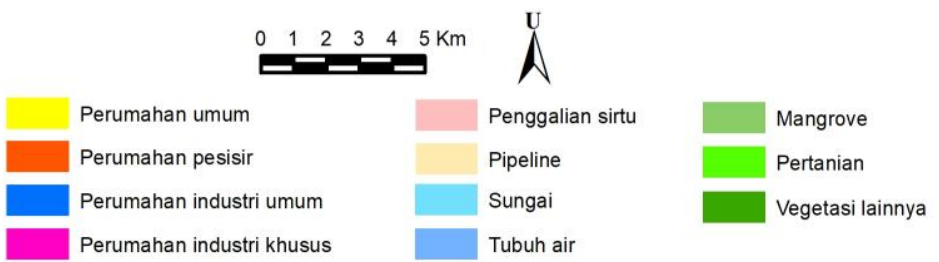

Gambar 9 Penggunaan lahan Tahun 2016 dan prediksi Tahun 2023

Hasil prediksi menunjukkan bahwa permukiman (perumahan umum, perumahan pesisir, perumahan industri umum dan industri khusus) merupakan penggunaan yang mengalami peningkatan paling besar mencapai 342 ha, disusul penggunaan pertanian yang 
meningkat hingga 250 ha. Sedangkan penggunaan yang mengalami penurunan luas terbesar adalah vegetasi lainnya mencapai 538 ha.

Kelurahan belimbing diprediksi mengalami peningkatan luas permukiman yang paling besar mencapai 62 ha, tetapi secara rasio yang terbesar adalah kelurahan guntung karena mengalami peningkatan hingga 129\% dibanding tahun 2016. Pusat sebaran perumahan dari tahun 2002 hingga tahun 2016 berada di wilayah utara Kota Bontang dengan kecenderungan bergeser ke arah barat-selatan, dan pada tahun 2023 diprediksi bergeser ke selatan-timur. Pergeseran secara umum mengarah ke barat karena sisi timur Kota Bontang dibatasi oleh perairan Selat Makassar. Pola penyebarannya adalah menyebar dengan kecenderungan semakin memanjang berbentuk oval vertikal mengarah utaraselatan.

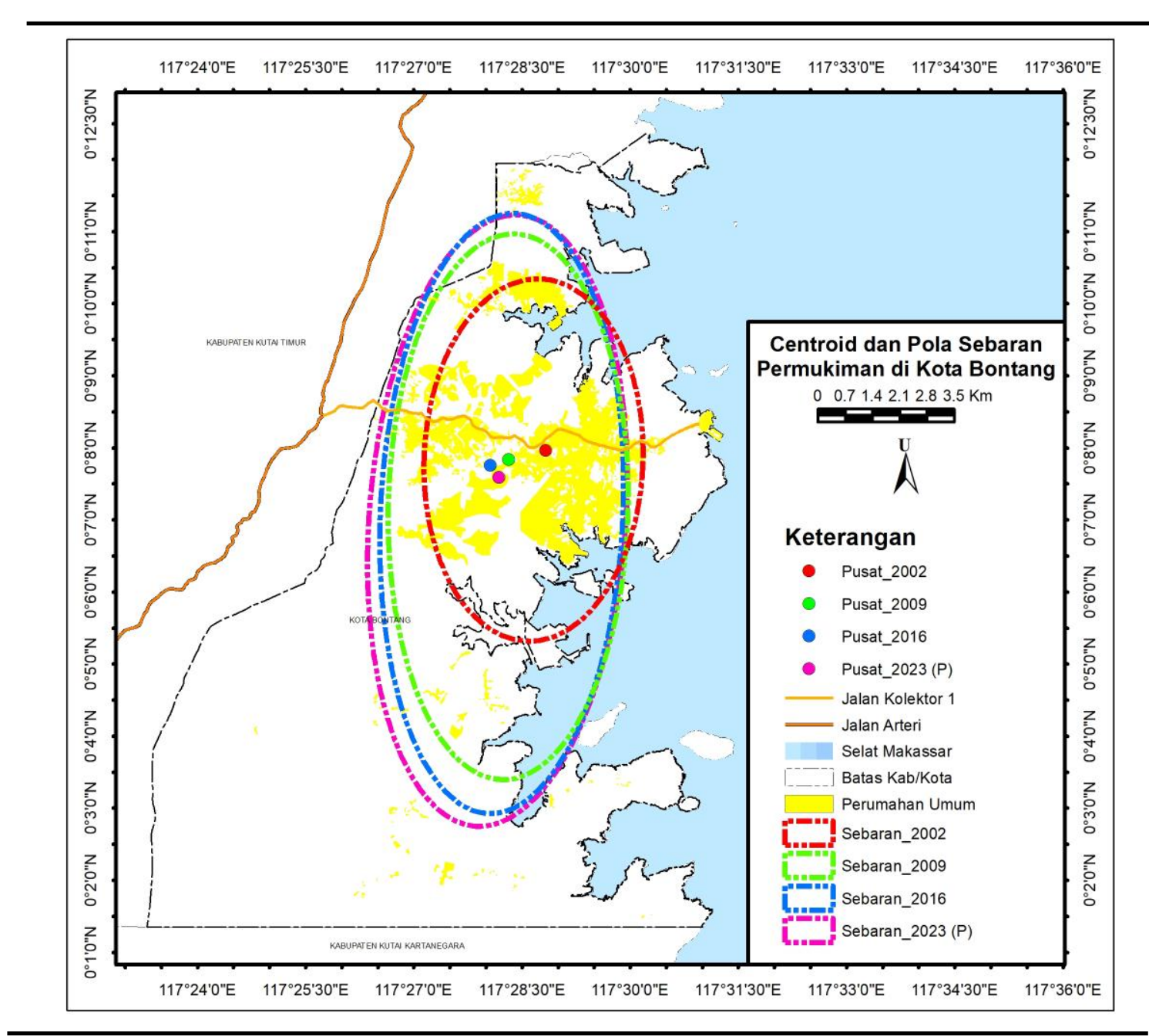

Gambar 10 Centroid dan Pola Sebaran Permukiman

\section{Analisis kesesuaian dan ketersediaan lahan permukiman}

Hasil evaluasi menunjukkan kelas sesuai mencapai 7.300,5 ha atau 46,1\% sedangkan kelas tidak sesuai mencapai 8.537 ha atau 53,9\%. Kesesuaian permukiman tersebut kemudian di overlay dengan kawasan kehutanan di Kota Bontang. Hasilnya menunjukkan kelas sesuai menjadi hanya $4.864,1$ ha atau sekitar $30,71 \%$. Sedangkan luas kawasan tidak sesuai (N1 dan N2) dan kawasan kehutanan (HPK, HL dan TNK) masing-masing sekitar 5.679 ha dan 5.294 ha 
Tabel 6 Hasil analisis kesesuaian lahan untuk permukiman dan kawasan hutan

\begin{tabular}{crrrrr}
\hline Sesuai & \multicolumn{1}{c}{ Luas } & Persentae & Tidak Sesuai & \multicolumn{1}{c}{ Luas } & \multicolumn{1}{c}{ Persentase } \\
\hline S1 & $1.971,7$ & 12,45 & N1 & $5.492,4$ & 34,68 \\
S2 & 657,4 & 4,15 & N2 & 186,9 & 1,18 \\
S3 & $2.235,0$ & 14,11 & HPK & 62,1 & 0,39 \\
Jumlah & $4.864,1$ & 30,71 & HL & $4.606,7$ & 29,09 \\
& & & TNK & 625,3 & 3,95 \\
& & & Jumlah & $10.973,3$ & 69,29 \\
\hline
\end{tabular}

Keterangan : S1: sangat sesuai, S2: cukup sesuai, S3: sesuai marginal, N1: tidak sesuai, N2: tidak sesuai permanen, HPK: Hutan Produksi yang dapat dikonversi, HL: Hutan Lindung, TNK: Taman Nasional Kutai,

Hasil analisis kesesuaian lahan permukiman dengan penggunaan lahan permukiman tahun 2016 menunjukkan bahwa 80\% penggunaan lahan permukiman berada di kelas sesuai, dan pada prediksi penggunaan lahan tahun 2023 menurun menjadi $76 \%$. Selain itu ternyata masih ditemukan adanya permukiman yang berada di dalam kawasan kehutanan (hutan lindung maupun taman nasional) walaupun luasnya relatif kecil $<1 \%$, namun berdasarkan hasil prediksi luasnya diperkirakan akan bertambah, diantaranya di Kelurahan Bontang Baru, Bontang Kuala dan Bontang Lestari.

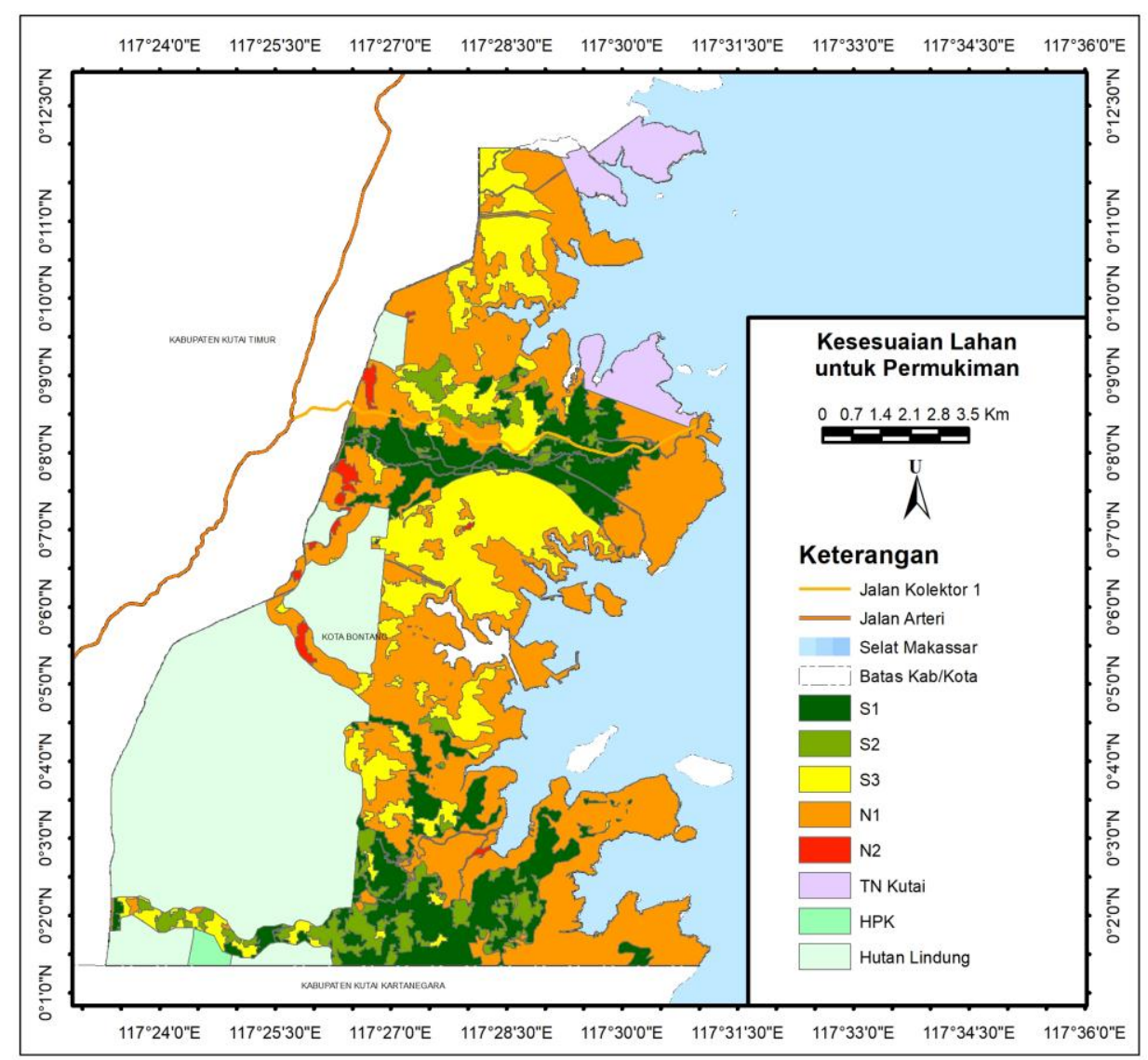

Gambar 11 Kesesuaian Lahan untuk Permukiman dan Kawasan Kehutanan

Hasil rincian kesesuaian lahan terhadap masing-masing tipologi perumahan, didapatkan bahwa perumahan industri khusus yang paling baik kesesuaiannya dengan $87 \%$ berada pada lahan sesuai, kemudian perumahan umum dan perumahan industri umum 
dengan $80 \%$ berada pada lahan sesuai, sedangkan perumahan pesisir hanya $5 \%$ yang berada pada lahan sesuai. Hal tersebut dikarenakan perumahan pesisir adalah rumah panggung yang berada diatas laut, sehingga secara umum masuk dalam kawasan tidak sesuai. Sedangkan berdasarkan hasil prediksi, perumahan industri khusus dan industri umum masih memiliki persentase yang sama yaitu $87 \%$ dan $80 \%$, sedangkan perumahan umum menurun menjadi $75 \%$.

Ketersediaan lahan permukiman didapatkan berdasarkan kesesuaian lahan permukiman, kawasan kehutanan, pola ruang RTRW Kota Bontang, penggunaan lahan tahun 2016, dan penguasaan tanah skala besar, sehingga didapatkan lahan tersedia yang berada pada lahan sesuai, di luar kawasan kehutanan, selaras dengan peruntukan pola ruang, berada pada wilayah non terbangun dan di luar kawasan HGB/HP skala besar milik perusahaan/industri.

Hasil menunjukkan ketersediaan lahan di Kota Bontang sekitar 1.475,7 ha, sedangkan ketersediaan lahan permukiman pada lahan sesuai hanya sekitar 951,5 ha atau kurang dari $6 \%$. Lokasinya tersebar dari utara hingga selatan, tetapi wilayah selatan atau Kelurahan Bontang Lestari lebih potensial karena berada pada satu hamparan yang luas dan berada dalam kelas S1

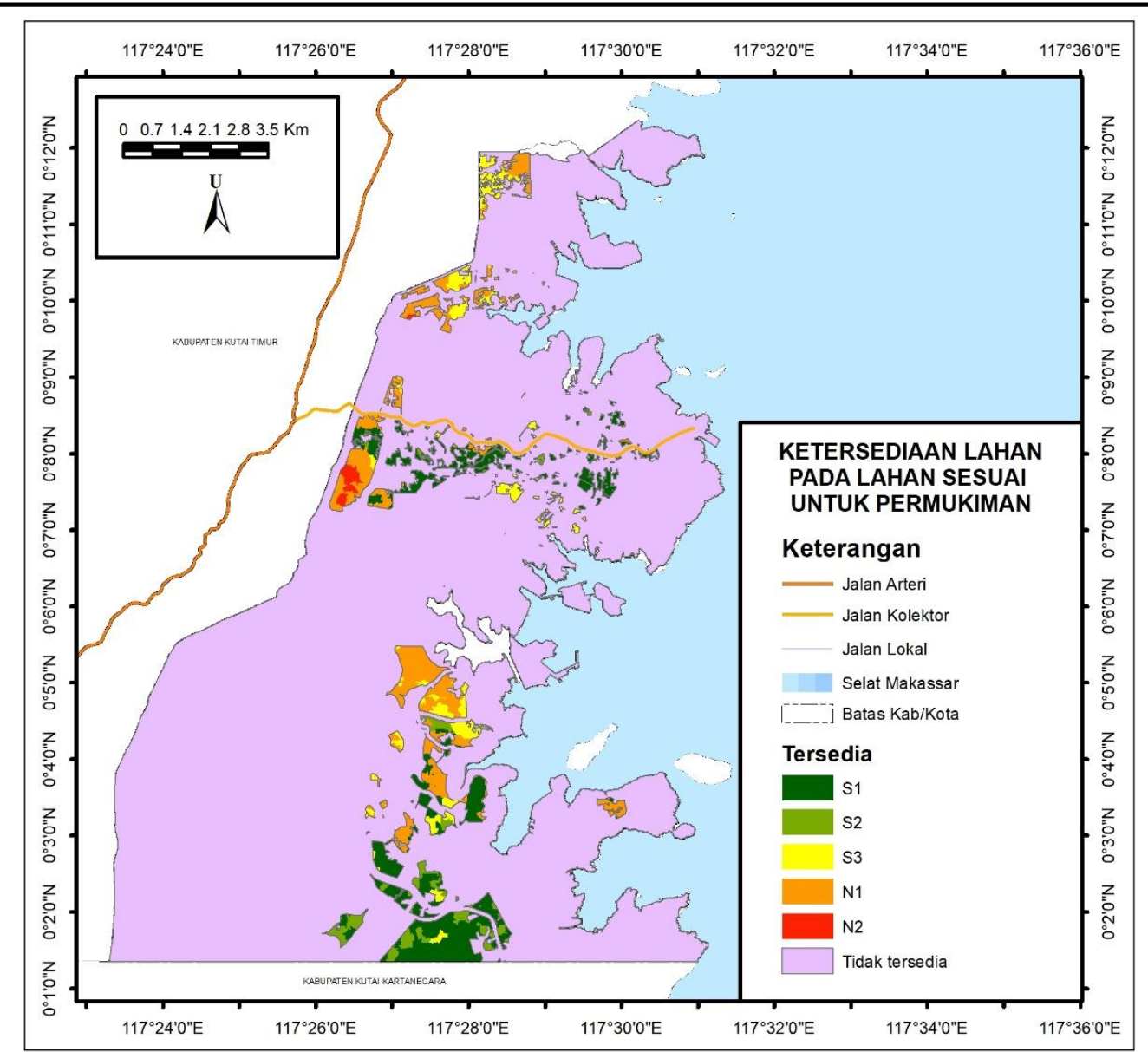

Gambar 12 Kesesuaian Lahan untuk Permukiman dan Kawasan Kehutanan

\section{Kebutuhan lahan permukiman}

Berdasarkan hasil perhitungan didapatkan persentase sarana prasarana dalam kawasan permukiman di Kota Bontang sebesar 40\%, dan luas kebutuhan lahan untuk 
permukiman pada tahun 2016 sebesar 715 ha dan 1,430 ha untuk asumsi masing-masing lahan kavling $100 \mathrm{~m}^{2}$ dan $200 \mathrm{~m}^{2}$, sedangkan kebutuhan lahan permukiman pada tahun 2023 adalah 795,6 ha dan 1.591,3 ha untuk masing-masing lahan kavling $100 \mathrm{~m}^{2}$ dan $200 \mathrm{~m}^{2}$.

Kebutuhan lahan permukiman hingga tahun 2050 dengan asumsi luas kavling lahan $200 \mathrm{~m}^{2}$ adalah sekitar 2.179,8 ha. Jika disandingkan dengan luas lahan permukiman eksisting dan ketersediaan lahan untuk permukiman dan dikurangi dengan lahan perumahan industri khusus sekitar 2.397,6 ha. Hal itu menunjukkan bahkan dengan asumsi lahan kavling rata-rata $200 \mathrm{~m}^{2}$ ketersediaan lahan di Kota Bontang masih mencukupi, terlebih bila lahannya lebih kecil atau dibangun perumahan vertikal seperti rumah susun. Perhitungan kebutuhan lahan untuk permukiman disajikan pada Tabel 7.

Tabel 7 Kebutuhan lahan permukiman di Kota Bontang

\begin{tabular}{|c|c|c|c|c|c|c|c|c|}
\hline \multirow[t]{2}{*}{ Tahun } & \multirow[t]{2}{*}{$\begin{array}{l}\text { Jumlah } \\
\text { Penduduk }\end{array}$} & \multirow[t]{2}{*}{$\begin{array}{l}\text { Unit } \\
\text { rumah }\end{array}$} & \multicolumn{2}{|c|}{$\begin{array}{l}\text { Luas kavling } \\
\text { (ha) }\end{array}$} & \multicolumn{2}{|c|}{ Luas Sarpras (ha) } & \multicolumn{2}{|c|}{$\begin{array}{l}\text { Luas kebutuhan } \\
\text { Total (ha) }\end{array}$} \\
\hline & & & $100 \mathrm{~m}^{2}$ & $200 \mathrm{~m}^{2}$ & $100 \mathrm{~m}^{2}$ & $200 \mathrm{~m}^{2}$ & $100 \mathrm{~m}^{2}$ & $200 \mathrm{~m}^{2}$ \\
\hline 2016 & 166.868 & 41.717 & 417,2 & 834,3 & 298,0 & 596,0 & 715,1 & $1.430,3$ \\
\hline 2023 & 185.648 & 46.412 & 464,1 & 928,2 & 331,5 & 663,0 & 795,6 & $1.591,3$ \\
\hline 2032 & 209.257 & 52.314 & 523,1 & $1.046,3$ & 373,7 & 747,3 & 896,8 & $1.793,6$ \\
\hline 2050 & 254.313 & 63.578 & 635,8 & $1.271,6$ & 454,1 & 908,3 & $1.089,9$ & $2.179,8$ \\
\hline
\end{tabular}

\section{KESIMPULAN}

Penggunaan lahan yang dominan di Kota Bontang pada tahun 2002 dan 2009 adalah hutan, semak, mangrove, permukiman, industri, dan ladang, sedangkan pada tahun 2016 penggunaan lahan dominan tetap sama tetapi mengalami perubahan urutan yaitu semak, hutan, mangrove, permukiman, ladang dan industri. Penggunaan lahan yang paling banyak mengalami perubahan selama periode tahun 2002-2016 adalah hutan dan semak, sedangkan penggunaan lahan yang paling banyak menjadi tujuan akhir dari perubahan adalah permukiman. Penggunaan lahan permukiman pada tahun 2023 diprediksi mengalami peningkatan paling besar mencapai 342 ha dan disusul penggunaan lahan pertanian yang meningkat sekitar 250 ha. Sedangkan penggunaan lahan vegetasi lainnya diperkirakan mengalami penurunan hingga 538 ha.

Lahan yang sesuai untuk permukiman (S1, S2, S3) di Kota Bontang sekitar 4,864.1 ha atau $31 \%$. Sedangkan luas kawasan tidak sesuai (N1 dan N2) dan luas kawasan kehutanan (HPK, HL dan TNK) masing-masing adalah 5.679 ha dan 5.294 ha. Kebutuhan lahan untuk permukiman di Kota Bontang pada tahun 2016 dan 2023 masing-masing adalah 1.430,3 ha dan 1.591,3 ha. Ketersediaan lahan permukiman pada lahan sesuai di luar lahan permukiman eksisting mencapai 941,5 ha yang masih dapat memenuhi kebutuhan hingga tahun 2050.

\section{UCAPAN TERIMA KASIH}

Ucapan terima kasih disampaikan kepada Pusat Pembinaan dan Pendidikan Pelatihan Perencana Badan Perencanaan Pembangunan Nasional (Pusbindiklatren Bappenas) yang telah mendukung pendanaan penelitian ini, serta para pihak yang telah membantu dalam penelitian ini.

\section{DAFTAR PUSTAKA}

Batudoka Z. 2005. Kota Baru dan Aspek Permukiman Mendepan. Jurnal Smartek 3(1):27-36

[BPS] Badan Pusat Statistik. 2015. Hasil Survey Penduduk Antar Sensus 2015. Jakarta (ID): Badan Pusat Statistik. 
Budiman PW, Antariksa, Usman F. 2010. Pelestarian Pola Permukiman Kampung Bontang Kuala Kota Bontang. Arsitektur e-jurnal. 3(1): 24-39.

Dwinanto AAP, Munibah K, Sudadi U. 2016. Model Perubahan dan Arahan Penggunaan Lahan untuk Mendukung Ketersediaan Beras di Kabupaten Brebes dan Kabupaten Cilacap. Tataloka 18(3):157-171.

Fahmi FZ, Hudalah D, Rahayu P, Woltjer J. 2014. Extended Urbanization in Small and Medium-size Cities: The Case of Cirebon, Indonesia. Habitat International. 42:1-10.

[FAO] Food and Agriculture Organization. 2007. Land Evaluation Towards A Revised Framework. Rome (IT): FAO-UN.

Harahap FR. 2013. Dampak Urbanisasi bagi Perkembangan Kota. Jurnal Society. 1(1):35-45

Hidayat W, Rustiadi E, Kartodihardjo H. 2015. Dampak Pertambangan Terhadap Perubahan Penggunaan Lahan dan Kesesuaian Peruntukan Ruang (Studi Kasus Kabupaten Luwu Timur, Provinsi Sulawesi Selatan). Jurnal Perencanaan Wilayah dan Kota. 26(2): 130-146

Jat MK, Choudhary M, Saxena A. 2017. Urban Growth Assessment and Prediction Using RS, GIS and SLEUTH Model for a Heterogeneous Urban Fringe. The Egyptian Journal of Remote Sensing and Space Science. 20(2):223-241.

Luo H, Huang B, Liu X, Zhang K. 2011. Green Roof Assessment by GIS and Google Earth. Procedia Environment Sciences. 10:2307-2313.

Malarvizhi K, Kumar SV, Porchelvan P. 2016. Use of High Resolution Google Earth Satellite Imagery in Landuse Map Preparation for Urban Related Application. Procedia Technology. 24:1835-1842.

Malau W. 2013. Dampak Urbanisasi Terhadap Permukiman Kumuh (Slum Area) di Daerah Perkotaan. Jupiis. 5(2):39-47

Munibah K, Sitorus SRP, Rustiadi E, Gandasasmita K, Hartrisari. 2009. Model Hubungan Antara Jumlah Penduduk dengan Luas Lahan Pertanian dan Permukiman (Studi Kasus DAS Cidanau, Provinsi Banten). Jurnal Tanah dan Lingkungan. 11(1):32-40

Nowar W, Baskoro DPT, Tjahjono B. 2015. Analisis Kesesuaian Lahan Komoditas Unggulan dan Arahan Pengembangannya di Wilayah Kabupaten Cianjur. Tataloka. 17(2):87-98.

Nurhidayati E, Buchori I, Mussadun M. 2016. Prediksi Perkembangan Lahan Permukiman terhadap Kerentanan Bencana Banjir dan Kebakaran di Permukiman Tepian Sungai Kapuas Kota Pontianak. Tataloka. 18(4):249-260.

Pigawati B, Yuliastuti N, Mardiansjah FH. 2017. Pembatasan Perkembangan Permukiman Kawasan Pinggiran Sebagai Upaya Pengendalian Perkembangan Kota Semarang. Tataloka. 19(4): 306-319

Prabowo DP, Bachri S, Wiwoho BS. 2017. Prediksi Perubahan Penggunaan Lahan dan Pola Berdasarkan Citra Landsat Multiwaktu dengan Land Change Modeller (LCM) Idrisi Selva 17: Studi Kasus Sub-DAS Brantas Hulu. Jurnal Pendidikan Geografi. 22(1): 32-48

Pribadi DO, Shiddiq D, Ermyanila M. 2006. Model Perubahan Tutupan Lahan dan Faktor-Faktor yang Mempengaruhinya. Jurnal Teknik dan Lingkungan. 7(1):35-51.

Ruslisan, Zahira FS, Dharmasanti R. 2015. Prediksi Perubahan Penggunaan Lahan Terbangun Terhadap Kesesuaian Rancangan Tata Ruang Wilayah Menggunakan Regresi Logistic Binner Berdasar Data Spasial dan Penginderaan Jauh di Kota Semarang. Conference on Urban Studies and Development. Hal:51-67.

Rustiadi E, Saefulhakim S, Panuju DR. 2011. Perencanaan dan Pengembangan Wilayah. Jakarta (ID): Crestpent Press dan Yayasan Pustaka Obor Indonesia.

Sadesmesli I, Baskoro DPT, Pravitasari AE. 2017. Daya Dukung Lahan dalam Perencanaan Tata Ruang dalam Perencanaan Tata Ruang Wilayah (Studi Kasus Kabupaten Blitar, Jawa Timur). Tataloka 19(4):1-12.

Sadyohutomo, M. 2016. Tata Guna Tanah dan Penyerasian Tata Ruang. Yogyakarta (ID): Pustaka Pelajar

Samad T, Yuwono TE, Lee MJ, Shi T, Poesoro AAL, Steele M, Nasution F. 2016. Kisah Perkotaan di Indonesia. Jakarta (ID): The World Bank Office Jakarta.

Septiono DS, Mussadun. 2016. Model Perubahan Penggunaan Lahan untuk Mendukung Rencana Pengelolaan Kesatuan Pengelolaan Hutan (Studi Kasus KPH Yogyakarta). Jurnal Pembangunan Wilayah dan Kota. 12(3): 277-292.

Sitorus SRP, Leonataris C, Panuju DR. 2012. Analisis Pola Perubahan Penggunaan Lahan dan Perkembangan Wilayah di Kota Bekasi Provinsi Jawa Barat. Jurnal Ilmu Tanah dan Lingkungan. 14(1):21-28.

Susetyo B, Widiatmaka, Arifin HS, Machfud, Arifin NHS. 2014. Analisis Spasial Kemampuan dan Kesesuaian Lahan untuk Mendukung Model Perumusan Kebijakan Manajemen Lanskap di Sempadan Ciliwung, Kota Bogor. Majalah Ilmiah Globe. 16(1):51-58. 
Widiatmaka, Ambarwulan W, Purwanto MYJ, Setiawan Y, Effendi H. 2015. Daya Dukung Lingkungan Berbasis Kemampuan Lahan di Tuban, Jawa Timur. Jurnal Manusia dan Lingkungan. 22(2):247-259.

Widiatmaka, Ambarwulan W, Setiawan Y, Walter C. 2016. Assessing the Suitability and Availability of Land for Agriculture in Tuban Regency, East Java, Indonesia. Applied and Environmental Soil Science. 1:1-13

Yudarwati R, Sitorus SRP, Munibah K. 2016. Arahan Pengendalian Perubahan Penggunaan Lahan Menggunakan Markov-Cellular Automata di Kabupaten Cianjur. Tataloka. 18(4): 211-221 